Happy in the service of the Company: the purchasing power of VOC salaries at the Cape in the $18^{\text {th }}$ century

SOPHIA DU PLESSIS AND STAN DU PLESSIS

Stellenbosch Economic Working Papers: 01/12

January 2012

KEYWORDS: REAL WAGES, DUTCH EAST INDIA COMPANY (VOC), CAPE COLONY, COMPARISONS OF LIVING STANDARDS, ECONOMIC HISTORY OF SOUTH AFRICA, ECONOMIC HISTORY OF THE CAPE COLONY

JEL: N37, N97, E31

SOPHIA DU PLESSIS DEPARTMENT OF ECONOMICS UNIVERSITY OF STELLENBOSCH

PRIVATE BAG X1, 7602

MATIELAND, SOUTH AFRICA

E-MAIL: SOPHIA@SUN.AC.ZA
STAN DU PLESSIS DEPARTMENT OF ECONOMICS UNIVERSITY OF STELLENBOSCH

PRIVATE BAG X1, 7602

MATIELAND, SOUTH AFRICA

E-MAIL: STAN@SUN.AC.ZA 


\title{
Happy in the service of the Company: the purchasing power of VOC salaries at the Cape in the $18^{\text {th }}$ century
}

\author{
SOPHIA DU PLESSIS AND STAN DU PLESSIS ${ }^{1}$
}

\begin{abstract}
This paper contributes to the debate on the level and trajectory of welfare at the Cape of Good Hope during the $18^{\text {th }}$ century. Recent scholarship (for example, Allen 2005) has calculated and compared the levels and evolution of real wages in various European and Asian economies since the early modern period. To this literature we add evidence for unskilled and skilled workers of the Dutch East India Company at the Cape of Good Hope during the $18^{\text {th }}$ century, following De Zwart (2009; 2011), who recently presented evidence for unskilled workers in the Cape for the latter half of the $17^{\text {th }}$ century and the $18^{\text {th }}$ century. We calculate jobspecific real wages in a three-step argument; from the narrowest international comparison of wage rates in terms of silver content to one based on a basket of widely consumed goods. The paper's contributions lie in the breadth of the comparisons, the inclusion of skilled workers in the comparison and the adaptation of the consumption basket to local conditions and relative prices at the Cape. The results support the hypothesis that at the start of the $18^{\text {th }}$ century, the Cape Colony was relatively poor on an international comparison, but as the century unfolded, gained considerably on even the richest contemporary societies.
\end{abstract}

Keywords: Real wages, Dutch East India Company (VOC), Cape Colony, Comparisons of living standards, Economic history of South Africa, Economic history of the Cape Colony

JEL codes: N37, N97, E31

\footnotetext{
${ }^{1}$ We are grateful to Nico Katzke for invaluable research assistance, to Pim de Zwart for access to data and to Dr Hans Heese for help with terminology and sources. This paper was presented at the World Economic History Congress in Utrecht during August 2009 and at the Department of History at the University of Stellenbosch during October 2009.
} 


\section{Introduction}

Despite the optimistic name, the Cape of Good Hope hardly suggested an attractive turn in the career of a Dutch East India Company official in the first decades since Van Riebeeck's founding of the Cape Colony. By around 1700, and after 48 years of the colony's existence, an official at the Cape lived worse materially, not to mention culturally, than his counterparts back home in the Netherlands or in the Eastern hub of Batavia (Giliomee, 2004: 3, 5). But as the fortunes of the VOC declined internationally during the course of the $18^{\text {th }}$ century, its officials at the Cape enjoyed a happy rise in their living standards relative to their peers in Holland. We trace that rise in the pages that follow and show that the underlying cause was not a change in the remuneration of VOC officials, but a dramatic change in what their salaries could buy. We observe a sharp rise in real wages as prices declined for essential consumption goods, with the slowly expanding market economy at the Cape.

\section{The economy of the eighteenth-century Cape Colony}

The Cape Colony was founded in 1652 by the VOC to serve as a refreshment station for the trade route between Europe and the Indies. As the native Khoi could at best supply some meat for the passing ships, Governor Jan van Riebeeck allowed a number of VOC employees to grow wheat and (later) wine on the slopes of Table Mountain, with agriculture later to spread towards the fertile agricultural land west of the Drakenstein and Hottentots Holland mountains. Despite the geographical expansion, agricultural production increased only slowly, with several decades passing before the colony could feed itself (Ross, 1986: 59). And further expansion was initially checked by the prohibitive transport costs across these mountain ranges.

The climate, which favours European crops such as wheat and wine, and the distance from European markets, prevented the Cape of Good Hope from becoming a booming export colony in the $17^{\text {th }}$ century. This is not to claim that exports were non-existent, and there were notable opportunities to export European products to European communities in the tropics (Ross, 1986), and wine elsewhere in the Southern hemisphere (Van Zyl, 1966) where geography gave the cost advantage to the Cape, but these trade routes did not constitute an export-led boom (Giliomee, 2004: 10). This left the local market, comprising the urban centre at Cape Town, where most of the proportionally large group of VOC employees lived and worked, where non-agrarian free burgers plied various trades, and where a large number of urban slaves laboured.

A service economy emerged in Cape Town that not only catered for the circulating population of sailors, but also provided maintenance and supplies to the ships for the next leg of their journeys. This economy included, inter alia, taverns, lodging, shops, bakers, brewers, builders and carpenters (for residential and ship maintenance), smiths, coopers and potters (Ross, 1989).

The question of whether the external links effectively linked local and global markets has occupied South African economic historians to a considerable degree. On the one side, scholars argue that the local market was effectively monopolised by the Company. The free burghers were denied the right to a free market; they could sell their produce only to the Company, and it alone would set the price (De 
Zwart, 2009). Van Zanten (2011) and Fourie (2011) recently updated this view of low-level stagnation with evidence that there was stagnation at the Cape in the $18^{\text {th }}$ century, but at a relatively high level of wealth, even in an international comparison.

Against this view, Van Duin and Ross ${ }^{2}$ have argued that the local market expanded steadily during the course of the $18^{\text {th }}$ century, and was linked with international markets via international trade in goods and services (Ross, 1989). The support for this view is the steady expansion of agricultural output and the trend of commodity prices during that period, to which in this paper we add further evidence on the evolution of prices, consistent with their thesis.

\section{Data sources}

Three sources supplied the bulk of the data used in this paper. Firstly, price data for meat, wine and grain were calculated from the appendices in Van Duin and Ross (1987: Appendix 10, Table 2), while prices for beans, butter, meat, bread, soap, candles, lamp oil, cotton and fuel were taken from the Scheepssoldijboeken (Nationaal Archief, 2008). The 'Scheepssoldijboeken' are available in the VOC archive (at the National Archive) in The Hague ${ }^{3}$. This resource documents the administration of ships passing Cape Town during the 18th century, but also the goods that they purchased in the Cape.

Thirdly, the TEPC (transcription of Estate Papers of the Cape of Good Hope) (TEPC, 2008) made documents on auctions, wages and inventories available in pdf format, from which we gathered both wage and price data.

Salaries for VOC officials at the Cape were recorded in muster rolls, now held at the Cape Archives Repository, and the Nationaal Archief, The Hague. For this project, the wage data on the muster rolls were central, which left the large number of muster rolls from the Cape Archives Repository, where wage data is not available, out of consideration. However, the muster rolls from the Nationaal Archief do record wage data, and the records we used are listed in Appendix 1.

Of course, wages paid by the VOC might not reflect the cost of comparable labour on the open market, and these calculations, accordingly, do not present a reliable approximation of living standards for the colony as a whole. De Zwart (2009: 13) identifies two reasons that suggest the possible underestimation of real wages when using muster roll data: first the company paid its lowest officials (soldiers, who were also employed in some low-skilled tasks) less than the going wage rate for low-skilled workers amongst free burgers ${ }^{4}$. Second, company officials received a part of their remuneration in goods and services $^{5}$, such as company housing, though the value of these additional resources remains uncertain. De Zwart (2009: 13) concludes reasonably that real wage calculations based on the muster rolls offer a lower bound to the actual real wage at the Cape for this period.

\footnotetext{
2 See, for example, Van Duin and Ross (1987) and Ross (1986; 1989).

3 The authors are grateful to Pim de Zwart who used the data from the Scheepssoldijboeken in De Zwart (2011) and generously made it available for this study.

${ }^{4}$ De Zwart (2009) compared the salaries of soldiers on the muster rolls with the wage a free burger could earn in construction given by Biewenga (1999).

5 See especially Schutte (1979) for a discussion of these additional benefits.
} 
We compiled price series for grain and wine from the inventories, and prices for auctions held on the estates of the deceased. The series of auction lists used here (MOOC10) is available in pdf format in the TEPC database (TEPC 2008).

\section{Discussion of the wage data}

From the muster rolls, we recovered 4519 useable entries, comprising data from 1699 (Muster roll NA12653) to 1790 (Muster roll NA 12602). These muster rolls contain information on the specific occupation for which the VOC paid a monthly wage ('gagie' in guilders per month), which allowed us to arrange the data in eight sectors: Administration, Agriculture, Construction, Education, Church, Merchants, the Legal profession, Medicine, the Military, Shipping, Trades, and Transport. A brief discussion of the data (available electronically from the authors) follows.

\section{1 Administration}

We classified 352 entries in the database as being data applicable to employees in the VOC administration, with the first entries relating to 1699 and the last relating to 1756. Included in this group are administrators overseeing the following: 158 assistants (adsistent), 15 masters (baas), 65 book keepers (boekhouder), 3 governors of the Cape of Good Hope, 5 classified as help (for instance, in the kitchen, in the weapons room) (handlanger), 3 stewards, 7 mandoors (these are slaves who acted as foremen to other slaves), 2 caretakers (oppasser), 1 pokkagiemeester, 73 company representatives in the countryside (posthouders), 4 writers (schrijvers), and 11 vlaggeluij.

\subsection{Agriculture}

The agricultural sector consists of 158 entries in our database, with the first entries relating to 1699 and the last relating to 1756. The tasks of these workers included the following: 6 were cattle-herders (beestewagters), 4 were grass cutters (grasmaijers), 4 were landspasad, 2 were dairy farmers (melkboer), 5 were reed-cutters (riet kappers), 15 were rangers (veldwagters), 9 were deer hunters (wildschutters), 25 were gardeners (thuijniers) (including 12 head gardeners), and 87 were woodcutters (houtkappers) (including 7 head woodcutters, and 3 assistant woodcutters).

\subsection{Construction}

The construction sector consists of 214 entries in our database, with the first entries relating to 699 and the last relating to 1756, with the following distribution across occupations: 4 head carpenters (timmerlieden), 50 house carpenters, 9 ship carpenters, 4 assistant carpenters, 6 turners (draaijer), 1 sculptor (beeldhouwer), 25 fortificatiewerkers, 1 head stonebreaker and 10 stonebreakers (klippebreekers), 43 messelaars (including 2 master messelaars and a messelaars assistant). 


\subsection{Education}

There were only three teachers in the database for the first half of the $18^{\text {th }}$ century, Adolf Hofman (earning a wage of 10 guilders per month in 1724 and 1726), Johannes Soigne (who was paid 9 guilders per month in 1724 and 1726) and Gotlieb Ramst, with a much higher 20 guilders per month in 1756. These wages are strikingly low in absolute and relative terms. By comparison, woodcutters and gardeners regularly received 14 guilders per month.

\section{5 The Church}

Sixty-seven VOC employees in our database served the Church in some capacity during the sample period, including 3 sextants, 1 organist, 1 independent minister (independend predicant), 1 adrichem, 30 ministers (predicant), 9 readers (voorleezer), and 22 sick comforters (krankbesoekers) serving Cape Town, Stellenbosch, the Swartland and Drakensteijn.

\section{6 Merchants}

By the nature of the VOC's business, merchants were important company officials (distinguished as 'qualified persons' on the muster rolls), and our records include 75 merchants (koopman), of which 53 were assistant merchants and 9 were head merchants ${ }^{6}$. There is no evidence of a trend in the nominal wage of any of these three categories over time though.

\section{7 The Legal Profession}

There are 217 entries for the legal profession in our database, including 117 assistants (in the police, the secretary of justice, the orphanage and the warehouse), 13 messengers (bodes), 44 book keepers (boekhouder), 3 jailers (cipier), 19 constables, 1 corporal, 1 fiscal (fiscaal), 4 geweldiger, 1 steward of the court (hofmeester), 8 writers (schrijver), and 5 substitute magistrates (subsistut landdrost).

\section{8 Medicine}

For the medical sector, we classified 50 entries in our database, including 5 chemists (apotheker), 9 surgeons (chirurgijn, of which one was a master and 3 assistants), 25 masters of medicine in various positions of the hierarchy (oppermeester, tweede meester, derde meester, etc.), 3 ziekentroosters and 4 ziekvaders (of which 2 were provisional).

\section{9 The Military}

The military sector is the largest sector in the database, consisting of 2538 data points, covering the longest period (up to 1790). Within this sector, we classified the following positions: 9 adjutants (adju-

\footnotetext{
6 About a third of these merchants were originally from Amsterdam, the largest of the seven chambers that comprised the VOC.
} 
dant), 3 bombardiers, 58 fusiliers (bosschieters), 10 cadets, 14 captains, 7 captain lieutenants, 18 lieutenants, 2 lieutenant colonels, 1 colonel, 9 constables (of which 4 were constable mates), 173 corporals, 1 extraordinary lieutenant, 3 garrison writers (guarnisoen schrijver), 1 garrison servant, 14 helpers (handlangers), 2 majors, 12 pijpers, 3 rapport writers (rapport schrijver), 117 sergeants, 1986 soldiers (soldaat), 4 swordsmen (swaartvegers), 37 drummers (tamboer), 4 trumpeters (trompetter), 42 ensigns (vaandrig), and 1 troop sergeant-major (wagmeester).

\section{10 Shipping}

Shipping was important given the nature and purpose of the VOC's colony at the Cape of Good Hope, and unsurprisingly, the database has a large number (399) of entries for this sector, from 1699 to 1756. The associated occupations include 41 midshipmen (adelborst); 3 sailors (bootsgesel); 10 crew (bootsman), of which 3 were crew mates; 1 captain; 1 constable's mate (constapelsmaat); 1 equipage master (equipagie meester); 2 geldduijkers; 292 sailors (mattroos); 4 assistant steersmen (onder stuurman), 2 head steersmen; 5 sailmakers (zijlmaker); 7 skippers (schipper); 27 quartermasters (quartiermeester), and 3 shipping corporals (scheepscorporal).

\section{11 Trades}

In addition to the occupations of skilled tradesman (such as butchers and bakers), this is also the residual category of the database where occupations are grouped that do not fit into the other categories. In total, the sector comprised 224 entries from 1699 to 1756. It included the following: 24 coopers, of which 5 were head coopers (kuijper); 1 head butcher (baas slaagter); 20 wagon makers, of which 3 were head wagon makers (wagenmakers); 9 bakers (bakkers); 3 bookbinders (boekbinder); 5 bottlers (bottelier); 2 truss makers (breukbandmaker); 1 gun smith (bussemaker); 2 map makers (caartemaaker); 3 painters (cladschilders); 7 cooks, of which 3 were cooks mates; 5 glaziers (glasemaker); 1 haxelsnijder; 3 timber entry clerks (houtschrijvers); 4 gunstockmakers (lademakers); 1 surveyer (landmeter); 3 tanners (leerberijder); 6 millers, of which 1 was a servant (moolenaar); 1 watch maker (orlogiemaker); 2 pump makers (pompemakers); 1 pottery maker (pottebacker); 8 thatchers (rietdekkers); 9 gunmakers (roermakers); 1 sakkenaijer; 2 seegelslagers; 2 locksmiths (slotemaker); 2 brick bakers (steen pannebacker); 4 velleberijder; 17 wageon makers (wagonmakers); 7 saddlers (zadelmaker); 4 head smiths; 4 tinsmiths (blikslager); 10 coppersmiths (kooperslager); 1 locksmith (slootemaker); and 1 smith (groffsmit).

\section{12 Transport}

Finally, the extensive geographical spread of the colony ensured an important role for those who worked in the transport sector. We classified 220 entries in our database as relating to transport, including 138 wagon riders (wagenrijder, karrerijders), of which 2 were head wagon riders; 3 heads at the barn (baas aan de schuur); 4 coachmen (coetsier); and 65 stable hands (stalknegts), of which 8 were stable masters (baas aan de schuur, stalmeester). 


\section{Discussion of the price data}

While nominal wages reveal the primary distribution between employees in the different occupations, they do not indicate what bundle of goods and services the salaried worker could buy; they do not identify standards of living. To calculate changes in living standards, we needed to calculate real wages, to which end we constructed a total price index from the prices of goods that would have accounted for substantial proportions of the regular expenditure of a household in the $18^{\text {th }}$ century. Table 2.1 in Appendix 2 lists the sources, original units of measurement and conversion formulae to guilders, kilograms and litres, while the time series data is available electronically from the authors.

\subsection{Meat}

We have two price series for meat, one from Van Duin and Ross and one from the Scheepsoldijboeken. Van Duin and Ross (1987: Appendix 10, Table 2) provide the prices paid by the VOC for meat supplied to the Company for a number of years, starting in 1701 and ending in 1793 . We created an annual time series from 1699 to 1793 by the linear interpolation of the data series and by assuming that the values for 1699 and 1700 were the same as for 1701. While these assumptions doubtless lead to inaccuracy at any particular point in time, they are unlikely to distort the long-run trend of the price series, which is the concern of this study. The series from the Scheepsoldijboeken is very similar to that of Van Duin and Ross, both in terms of levels and their variation over the century, with a correlation coefficient of 0.83 from 1701 to 1794 . Both series show a striking decline in the price of meat over the course of the $18^{\text {th }}$ century, by as much as $75 \%$ in the Van Duin and Ross series and $80 \%$ in the Scheepsoldijboeken. At the start of the century, the price of meat was 0.35 guilders per kilogram in Amsterdam $^{7}$ and 0.3 guilders in Cape Town, but by 1794 the price had fallen to 0.06 guilders in Cape Town and had risen to 0.42 guilders in Amsterdam. We used the price series from the Scheepsoldijboeken in the index calculations.

\subsection{Grain and Bread}

Van Duin and Ross (1987), the auction lists from estates at the Cape Colony (now available in the TEPC database), as well the Scheepsoldijboeken provide price data for grain (tarwe). Both the Van Duin and Ross (1987) data and the auction lists are necessary to create a price series from 1700 until 1793, with the auction lists providing the entries prior to 1749, the starting period of the Van Duin and Ross (1987) series. We recorded all prices for grain over the period 1685 to 1775 from the auctions, taking the median value for years with more than one entry. Where the data overlaps with the VOC data (during the 1760s and early 1770s), the auction prices are lower than the VOC prices, as expected ${ }^{8}$. To merge these data into a single price series for the period 1699 to 1793, we used the auction prices as

\footnotetext{
7 Van Zanden: 'The prices of the most important consumer goods, and indices of wages and the cost of living in the western part of the Netherlands, 1450-1800', http://www.iisg.nl/hpw/brenv.php.

8 The lower prices fetched for grain at auctions reflects (i) the premium paid by the VOC for grain delivered to Cape Town and (ii) the transport cost from the countryside to Cape Town.
} 
the base until 1749, and Van Duin and Ross's data from 1750 onwards. The auction prices for 1749 were used as the base for a new price series, together with the period-by-period changes in the Van Duin and Ross data, starting with the auction prices of 1749. The adjusted Van Duin and Ross data were then added to the auction data to form a single price series running to $1793^{\circ}$.

A further complication with this combined series is the inclusion of a small quantity of pulses in the export volumes, from which we derived the grain prices for the latter half of the $18^{\text {th }}$ century. While the inaccuracy is not likely to be large, since pulses rarely accounted for more than 5\% of exports, this figure was typically closer to $1-2 \%$ of the total export volume recorded in this series. Hence, this inaccuracy combined with the need to splice the data mid-century accounts for the decision to use the grain data from the Scheepsoldijboeken.

During this period, grain was typically consumed as a staple in the form of bread. However, De Zwart calculated his consumption basket with grain, and in order to compare his work, on the one hand, with that of Allen and others (2011), on the other, who used bread, we calculated consumption baskets alternatively with bread and grain. The bread price series in the Scheepsoldijboeken used here is for hard bread (hardebood, made from flour, salt and water) a major component of soldier rations in this period. The price series for bread and grain are highly correlated over the course of the century (with a correlation coefficient of .087), though the cumulative decline in the price of bread (around 38\%) exceeded that of grain (around 31\%).

\subsection{Wine}

Van Duin and Ross (1987: Appendix 5, Tables $1 \& 4$ ) provide export data (values and volumes at an annual frequency) for the export of wine by the VOC from the Cape for the period 1749 to 1793. This data could be used to calculate an annual price series over the relevant sample. Meanwhile, auction data is available for the earlier half of the $18^{\text {th }}$ century and was used to trace the price of wine from the late $17^{\text {th }}$ century onwards and we used the median value for years with more than one entry.

To create a single series, we spliced the Van Duin and Ross data with the data for the auction in 1747, using the auction data's level in that year as the base level for the Van Duin and Ross data from that point onwards. Wine auctions recorded volatile wine prices during the first half of the century, against an upward trend, rising by about $60 \%$ over the first half of the $18^{\text {th }}$ century. Prices stabilised from that point onwards, and the cumulative rise in wine prices between 1700 and 1794 was 57\%.

\subsection{Beans}

The Scheepsoldijboeken provides a complete list of the prices of beans sold to ships passing the Cape of Good Hope for the years between 1706 and 1794. Price data is only available from 1706 onwards, and assuming the same price for 1706, values were filled in for 1700 to 1705 . The price of beans shows a steady decline throughout the period, leaving beans 58\% cheaper in 1794 than in 1706.

\footnotetext{
9 The unusually high auction value for 1708 (nearly twice as high as neighbouring values) created additional difficulties. This value will greatly affect the base value of the series in 1700 , and if incorrect will exaggerate the decline in the grain price index during the course of the 18 th century.
} 


\subsection{Butter}

The price of butter was also recorded in the Scheepsoldijboeken, though the series was patchy, with entries for the following years only: 1708, 1716, 1717, 1720, 1741, 1748, 1760-1764, 1769, 1783, 1784, 1786, 1789-1791 and 1793. The series was completed through a process of linear interpolation, and the price for 1700 was assumed to be the same as for 1708. The price for butter rose sharply at the start of the century, nearly tripling by 1714 , but then declined again to end 1794 at a level not very different from the price in 1708 .

\subsection{Soap}

The price series for soap had to be constructed from three different data sources. The auction data has entries for 1708, 1714, 1751, 1752, 1755, 1756, and 1772. Two more data points (1716 and 1718) were collected from the Scheepssoldijboeken, while data for 1747-1750 and 1775 were collected from 'Prices Rendementen verkoop' (Nationaal Archief, (ref. no.) 1.04.02) ${ }^{10}$. It is assumed that the price of soap for 1700 was the same as for 1708 . The price of soap varied considerably over the course of the $18^{\text {th }}$ century, and by 1794 was 190\% more expensive than in 1708 .

\subsection{Cotton}

Since textiles are less homogenous than many of the other commodities discussed here, the construction of this price series presented specific challenges. While the auction lists record pieces of linen (stukke linne) of different kinds, they rarely show enough information to control for quality, size and age. As a result, the price series for cotton recorded in the Scheepssoldijboeken was the only practical source. This series showed at least three large cycles of price rises and declines during the course of the $18^{\text {th }}$ century and items were $40 \%$ cheaper by 1794 than they were in 1708 (the first entry in the Scheepssoldijboeken).

\subsection{Fuel}

Two fuels for lighting (candles and lamp oil) and one for heating (firewood) are typically included in consumption baskets for this period (Allen et al. 2011). The Scheepssoldijboeken recorded data for all three. Starting with the price series for lamp oil, in addition to two pronounced price spikes early in the $18^{\text {th }}$ century, the price of lamp oil rose steadily from the middle of the century onwards and the price of lamp oil was twice as expensive from the 1770s onwards than it had been in 1700 . The price of candles (wax kaarsen) rose modestly (by about $25 \%$ cumulatively) in the second and third quarters of the $18^{\text {th }}$ century, only to decline somewhat in the fourth quarter, prior a sharper price increase during the 1790s, which left candles 37\% more expensive in 1794 than in 1700 .

\footnotetext{
${ }^{10}$ We are grateful to Pim de Zwart for kindly sharing this data with us.
} 


\section{Living standards in an international comparison}

By combining the nominal wage series compiled above with the prices of goods consumed by typical households, it is possible to compare the living standards of families with breadwinners from particular occupations with families in different circumstances, both at the Cape and internationally. Such comparisons can be approached in a number of ways, three of which have been implemented here, starting with two simple comparisons and ending with a more elaborate comparison based on a basket of consumer goods. The calculations offered in this section extend De Zwart's (2009) recent comparison of standards of living at the Cape Colony from the mid $-17^{\text {th }}$ century to the early $18^{\text {th }}$ century and his more recent calculations for the $18^{\text {th }}$ century (De Zwart, 2011).

\subsection{A first comparison: silver wages}

Expressing the local wage in terms of an internationally comparable standard of value is an obvious way to proceed with the international comparison of standards of living. For the period under consideration, this means expressing the local wage in terms of silver for comparing silver wages elsewhere in the world at that time. This calculation presents no difficulties for the Cape Colony during this period as guilder wages have already been established, and the silver content of guilders remained constant (at 9.61 grams of silver per guilder) from 1681 onwards for the remainder of the period under considera$\operatorname{tion}^{11}$.

To complete this calculation, an assumption about the number of workdays per month is required to turn monthly guilders into an internationally comparable silver wage per day. Following De Zwart (2009), we assumed a total of 300 workdays per year, or 25 workdays per month ${ }^{12}$. The results of this comparison for an unskilled worker are shown in Table 1.

Table 1 Comparison of unskilled wages using silver content

\begin{tabular}{lllc}
\hline Period & Source & Location & Daily wage in grams of silver \\
\hline 1730 & Allen et al. (2005) & London & 10 \\
1790 & Allen et al. (2005) & London & 11 \\
1730 & Allen et al. (2005) & Amsterdam & 8.5 \\
1790 & Allen et al. (2005) & Amsterdam & 9 \\
1730 & This paper & Cape Town & 3.5 \\
1790 & This paper & Cape Town & 5 \\
\hline
\end{tabular}

The unskilled worker in this calculation is a soldier at the Cape, an assumption also made by De Zwart (2009).

\footnotetext{
11 The silver value of guilders are recorded as a part of the extensive "Historical Wages and Prices" database constructed by Van Zanden at the Institute of Social History in Utrecht and available online at: http://www.iisg.nl/hpw/brenv.xls.

12 This assumption is based on Allen's (2001) calculation of 300 workdays per year for a Protestant society in Northwest Europe at this time.
} 
The comparison of silver wages suggests that unskilled labourers lagged significantly behind their peers in the leading economic centres of North-Western Europe at the start of the $18^{\text {th }}$ century, a result consistent with De Zwart's (2009) calculations for the latter half of the $17^{\text {th }}$ century. The comparison is naturally more favourable with other cities in North-Western Europe and with towns in Southern England outside of London. For example, the silver wage for unskilled labour was 5.6 grams per day in Southern England by the late $17^{\text {th }}$ century (Broadberry and Gupta, 2006). More importantly, while wages expressed in silver remained largely constant in North-Western Europe ${ }^{13}$ over this period, they increased at the Cape, suggesting that workers at the Cape were catching up with their more affluent peers in Europe during the course of the $18^{\text {th }}$ century.

Silver wages are not, however, an adequate basis for comparing the purchasing power of wages internationally. The law of one price, which (after adjusting for transport costs) equalises the cost of goods and services internationally, does its work over a horizon of decades, and at any point in time, local prices can and do diverge greatly from prices elsewhere, even with extensive international trade. Because the same gram of silver bought a very different basket of goods in Cape Town and in Amsterdam, a more accurate estimate of the relative real wage in these cities can only be achieved by scaling the nominal wage by goods and services actually bought and consumed.

\subsection{A second comparison: the price of grain}

Parthasarathi (1998) took a methodologically simple approach to international comparisons of purchasing power by comparing the amount of grain a salary could purchase in local markets. Using this method, the nominal wage is expressed as equivalent to a certain number of pounds of grain per week; a ratio can then be compared across societies. Parthasarathi (1998) reported these calculations for Britain and India in the $18^{\text {th }}$ century, while the interest here is to compare the earnings of VOC employees at the Cape and similarly employed workers in Northern Europe. Table 2 shows the relevant results for Britain as calculated by Parthasarathi (1998) for the middle of the $18^{\text {th }}$ century (for lower and higher skilled weavers) and calculations for (lower skilled) soldiers and (higher skilled) carpenters at the Cape.

Table 2 Purchasing power of real wages in grain

\begin{tabular}{|c|c|c|c|}
\hline Period & Source & Occupation & Grain per week (pounds) \\
\hline Mid $18^{\text {th }}$ century & Parthasarati (1998) & Rural English weaver & $40-50$ pounds \\
\hline Mid $18^{\text {th }}$ century & Parthasarati (1998) & Spitalfields Silkweavers & $120-140$ pounds \\
\hline Early $18^{\text {th }}$ century & This paper & Soldier & 42 pounds \\
\hline Mid $18^{\text {th }}$ century & This paper & Soldier & 55 pounds \\
\hline Late $18^{\text {th }}$ century & This paper & Soldier & 70 pounds \\
\hline Early $18^{\text {th }}$ century & This paper & Carpenter & 74 pounds \\
\hline Mid $18^{\text {th }}$ century & This paper & Carpenter & 86 pounds \\
\hline
\end{tabular}

\footnotetext{
${ }^{13}$ London is an exception, with silver wages rising fast after 1790 (Allen, 2005).
} 
From Table 2, it appears that a low-skilled VOC employee had more than caught up with a low-skilled English weaver by the middle of the $18^{\text {th }}$ century, and more prosperity was to follow. Skilled employees were further behind their English peers in this comparison, though they too were catching up notably by mid-century.

But this calculation is also inadequate; the method exaggerates the importance of one price - that of the chosen staple - to the exclusion of all other information about the economy. For example, inventories survive that show a rich diet even in the household of a person like Joachim von Dessin, who arrived in the Cape as a VOC soldier in 1727. The thorough record of his household includes an inventory of his scullery, which included, inter alia, the following: wheat, flour, rice, groats and sago; a variety of beans (yellow, white, black, brown); spices, such as mustard, cumin, pepper and tamarind; sugar and coffee beans; oil and lard; meat (beef and pork); Vaderlandsche wine and wine from the Cape, as well as soap, wood and candles (Claassens, 2006: 118). Since the cost of living is inherently multi-dimensional, this radical economy in the comparison of wages and prices risks distorting the international comparison, as Allen has argued elsewhere (Allen, 2001).

\subsection{A third comparison: the cost of living}

De Zwart recently found that living standards at the Cape during the latter half of the $17^{\text {th }}$ century were lower than in the Netherlands, but not out of line with the experience of the rest of North-western Europe, and higher than elsewhere in Europe or in Asia (De Zwart, 2009: 5). Using very detailed price data from VOC correspondence in the National Archive, he was able to calculate the silver price of three consumption baskets at the beginning of the $17^{\text {th }}$ century. This is part of a larger body of international literature that compares standards of living across both time and societies by expressing nominal income relative to the cost of consumption baskets that attain certain levels of nutrition expressed in calories and protein. For example, Allen et al. (2005) propose two different baskets for the sake of such comparisons: a "barebones" basket which gives 1946 calories and 82 grams of protein per day, together with minimum requirements in terms of fuel, textiles and so on, while the calorie content of their "respectable" basket is higher at 2140 per day, and the other components of the basket are also adjusted upwards.

De Zwart (2011) based his welfare comparisons on baskets as close as possible to that of Allen et al. (2005). In this paper, we replicate his results and suggest some variations on the baskets, adjusted for local circumstances. Table 3 shows the "barebones" baskets of Allen et al. (2005) compared with De Zwart's (2011) "barebones" basket and two baskets proposed in this paper. The differences between the baskets of De Zwart and Allen et al. lie in De Zwart's use of grain (instead of bread) as the staple and the higher consumption of butter in the De Zwart basket. There is little to choose between in the nutritional value of either basket, with De Zwart's giving 1945 calories and 89 grams of protein per day in contrast to the 1946 calories and 82 grams per day of Allen et al.'s basket.

The decision by De Zwart to raise the consumption of butter relative the Northern-European basket of Allen et al. is justified by the known higher diary content of diets at the Cape. Following the same logic, the proposed baskets in this paper adjust the meat content of the local diet upwards at the cost of the 
staple consumption. We followed De Zwart in raising butter consumption (though not by as much) and Allen et al. in preferring bread to grain as the appropriate staple. "Basket 1" proposed here gives a comparable 1939 calories and 78 grams of protein per day.

There are good reasons for raising the meat content of the local baskets. First, as with diary, commentators on the colonial diet at the Cape emphasised the importance of meat. Botha (1962) describes the importance of meat in the diet of settlers. Second, the relative price of meat at the Cape encouraged meat consumption relative to bread. At the start of the $18^{\text {th }}$ century, for example, $1 \mathrm{~kg}$ of meat cost 2.27 times the cost of $1 \mathrm{~kg}$ bread in Amsterdam ${ }^{14}$, a ratio that was 2.75 at the Cape. As the $18^{\text {th }}$ century unfolded though, the price of meat rose dramatically in Holland, while it declined sharply at the Cape. By 1793, the price ratio between meat and bread was 3.65 in Amsterdam and only 0.82 at the Cape.

The second basket proposed in this paper is based more explicitly on the time variation in the relative price of meat and bread over the course of the $18^{\text {th }}$ century. This "economic" basket is the same as the Allen et al. "barebones" basket for Northern Europe, but allows for time-dependent combinations of bread and meat. In each year, "basket 2" is the cheapest combination of bread and meat that would satisfy minimum calorie requirements (1691 per day) as well as give no less than 70 grams of protein from bread and meat combined, subject to a minimum bread consumption of $150 \mathrm{~kg}$ per year ${ }^{15}$.

Table 3 Annual composition of "barebones" baskets

\begin{tabular}{llllll}
\hline Item & Unit & Allen et. al & De Zwart & Basket 1 & Basket 2 \\
\hline Grain & $\mathrm{Kg}$ & & 173 & & \\
Bread & $\mathrm{Kg}$ & 247 & & 223 & variable \\
Beans & $\mathrm{Kg}$ & 20 & 20 & 20 & 20 \\
Meat & $\mathrm{Kg}$ & 5 & 5 & 26 & variable \\
Butter & $\mathrm{Kg}$ & 3 & 5 & 4 & 3 \\
Soap & $\mathrm{Kg}$ & 1.3 & 1.3 & 1.3 & 1.3 \\
Candles & $\mathrm{Kg}$ & 1.3 & 1.3 & 1.3 & 1.3 \\
Lamp oil & $\mathrm{Litre}$ & 1.3 & 1.3 & 1.3 & 1.3 \\
Cotton & $\mathrm{m} 2$ & 3 & 3 & 3 & 3 \\
Fuel & MBTU & 3 & 3 & 3 & 3 \\
Calories per & & 1946 & 1945 & 1939 & \\
day & & 82 & 89 & 78 & \\
Grams of pro- & & & & & \\
tein per day & & & & & \\
\hline
\end{tabular}

Sources: Allen at al. (2005), De Zwart (2011), and own calculations.

\footnotetext{
14 The price of meat and bread in Amsterdam is from Van Zanden (2008).

${ }^{15}$ As stated, the rules of the second basket exhibit a linear programming problem that yields one of two baskets in any particular year. When meat is relatively expensive, the basket comprises $247 \mathrm{~kg}$ of bread and $5 \mathrm{~kg}$ of meat per year and switches to a basket with $150 \mathrm{~kg}$ of bread and $100 \mathrm{~kg}$ of meat when meat is relatively cheap.
} 
The evolution of these "barebones" baskets over the $18^{\text {th }}$ century given the price series discussed above is shown in Figure 1, after scaling each to an index value of 100 for the year 1700.

Figure 1 "Barebones" consumption indices for the Cape during the $18^{\text {th }}$ century

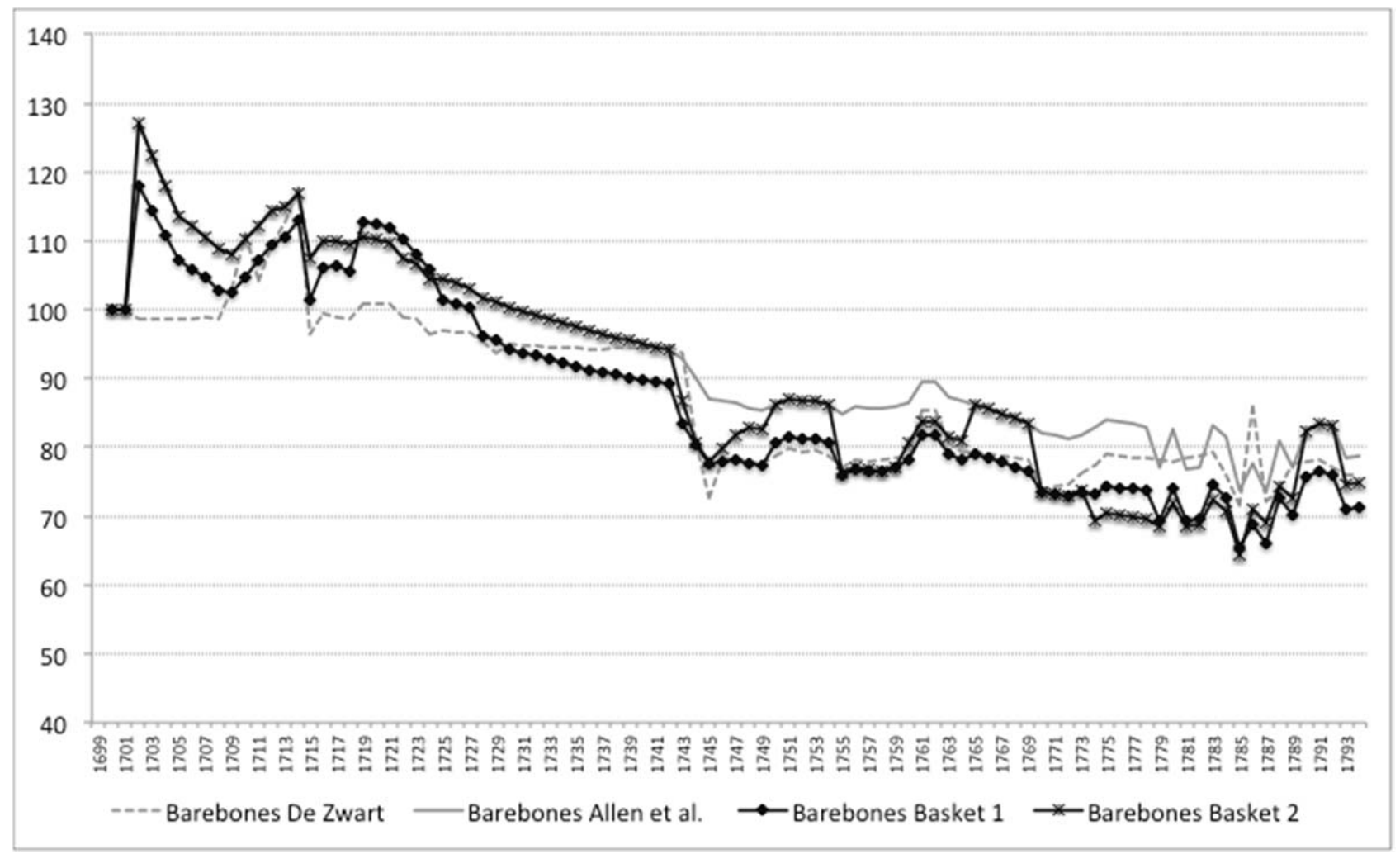

In all four cases, a substantial decline - in the order of 15\% - in the nominal cost of a "barebones" basket is observed over the period under consideration. Basket 1 showed the largest decline $(29 \%)$ due to the larger meat consumption, the price of which declined faster than the prices of most other large components of these baskets.

While the "barebones" basket provides for a minimum level of nutrition, a higher income would allow a person substantially greater nutritional value. Allen et al. (2005) proposed a "respectable" consumption basket to capture this higher potential standard of living. Their "respectable" basket as well as an adaption (basket 3) sensitive to the different relative prices of meat and bread were used in this paper as benchmarks. Table 4 shows the annual composition across products for the two "respectable" baskets used in this paper. 
Table 4 Annual composition of "respectable" baskets

\begin{tabular}{llll}
\hline Item & Unit & Allen et. Al & Basket 3 \\
\hline Grain & $\mathrm{Kg}$ & & \\
Bread & $\mathrm{Kg}$ & 247 & 168 \\
Beans & $\mathrm{Kg}$ & 20 & 20 \\
Meat & $\mathrm{Kg}$ & 5 & 45 \\
Butter & $\mathrm{Kg}$ & 3 & 3 \\
Soap & $\mathrm{Kg}$ & 1.3 & 1.3 \\
Candles & $\mathrm{Kg}$ & 1.3 & 1.3 \\
Lamp oil & $\mathrm{Litre}$ & 1.3 & 1.3 \\
Cotton & $\mathrm{m} 2$ & 3 & 3 \\
Fuel & $\mathrm{MBTU}$ & 3 & 3 \\
Wine & Litres & 70 & 70 \\
Calories per & & 2140 & 2140 \\
day & & 78 & 78 \\
Grams of pro- & & & \\
tein per day & & & \\
\hline
\end{tabular}

Sources: Allen at al. (2005) and own calculations

The evolution of the two "respectable" baskets given the price series is shown in Figure 2, scaled to 100 in 1700 . While the cumulative declines in the nominal value of these baskets are slightly less than for the "barebones" baskets, the declines are substantial: 15\% for the Allen et al. basket and 20\% for basket 3 . 
Figure 2 "Respectable" consumption indices for the Cape during the $18^{\text {th }}$ century

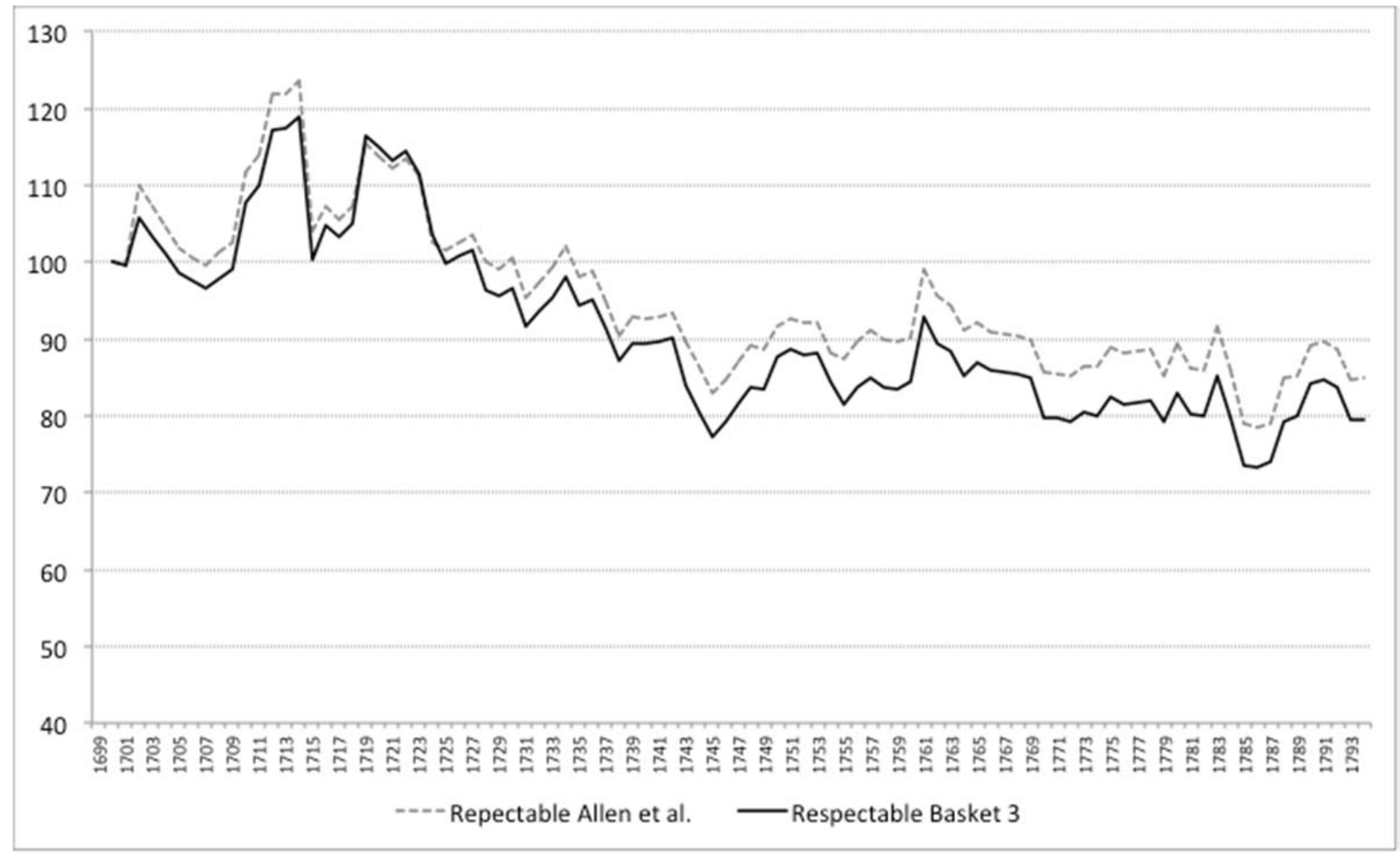

The ratio of a nominal wage series to the nominal cost of a consumption basket yields what, in this literature, has been called a welfare ratio. When it exceeds 1 , the ratio indicates that the wage is sufficient to cover the expenses associated with the consumption basket. Our interest here lies with the relative prosperity of a low-skilled worker and a higher-skilled worker at the Cape during the $18^{\text {th }}$ century in an international comparison. To that end, we chose a VOC soldier as being representative of a low-skilled worker, for whom we had extensive wage data, and a VOC clerk (or assistant) as an example of a higher-skilled worker ${ }^{16}$.

However, a number of adjustments are required before the nominal wage series from the muster rolls can be compared with the consumption baskets to calculate welfare ratios. First, the consumption basket has to be adjusted upwards to include housing costs. Following Allen et al. (2011) as well as De Zwart (2011), a rental cost of 5\% was added to the consumption basket. Second, a married worker's wage might support a family, and to allow for the family, it was assumed to require three times the consumption baskets specified above ${ }^{17}$. Third, De Zwart (2009) correctly observes that the VOC paid at least some part of a worker's remuneration in kind, though such payments were not recorded in the

\footnotetext{
16 The muster rolls contained nominal wage data for assistants until 1756, but with very little variation. A wage of 20 guilders per month seems to have been the going wage at this level during the $18^{\text {th }}$ century, and for the purposes of this paper, was assumed to hold until 1793. De Zwart (2011) also observed the small variation in nominal wages, and likewise, assumed that nominal wages remained constant for much of the century.

17 This is the same assumption used by De Zwart (2011), and was proposed by Allen at al. (2011), who reasoned that three times the consumption basket would yield the nutritional content required for a family of two adults and two small children.
} 
muster rolls, and there are no reliable records of their size. Consequently the welfare ratios presented below are likely to understate the real circumstances of the families under investigation.

A welfare ratio for soldiers is shown in Figure 3, where the nominal wage series was compared with the four "barebones" baskets. Figure 4 shows a welfare ratio for clerks, where the nominal wage series was compared with the two "respectable" baskets.

Figure 3 Welfare ratios for soldiers at the Cape during the $18^{\text {th }}$ century

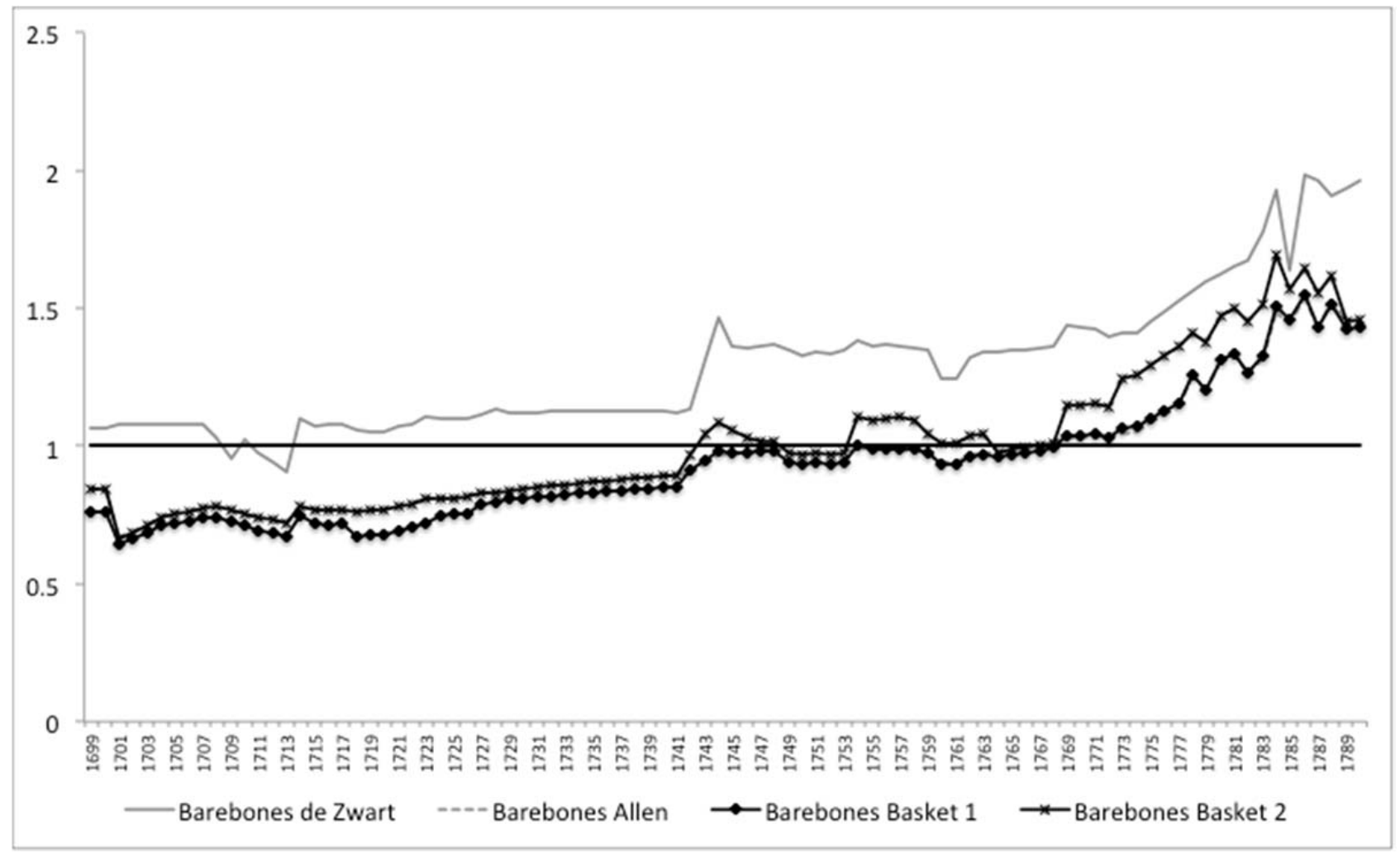

At the beginning of the $18^{\text {th }}$ century, a VOC soldier's wage would have supported a family at a fairly low level of welfare in absolute terms by comparison with the cost of various "barebones" baskets and also in an international comparison. Workers were better off on this measure in cities such as Amsterdam, Beijing, Leipzig, London and Milan. Despite stagnant nominal wages, the decline in the nominal cost of living at the Cape during the $18^{\text {th }}$ century raised welfare substantially towards the end of the century. By 1793, a worker at the Cape had closed the welfare gap with his peers in Leipzig (on average) and was ahead of those in Milan (Allen et al., 2011; De Zwart, 2011). The more skilled assistant started the century in a much better position, even when compared in terms of the cost of the "respectable" basket. Again, the decline in the cost of living raised the welfare ratio of assistants by $20-30 \%$. 
Figure 4 Welfare ratio for clerks at the Cape during the $18^{\text {th }}$ century

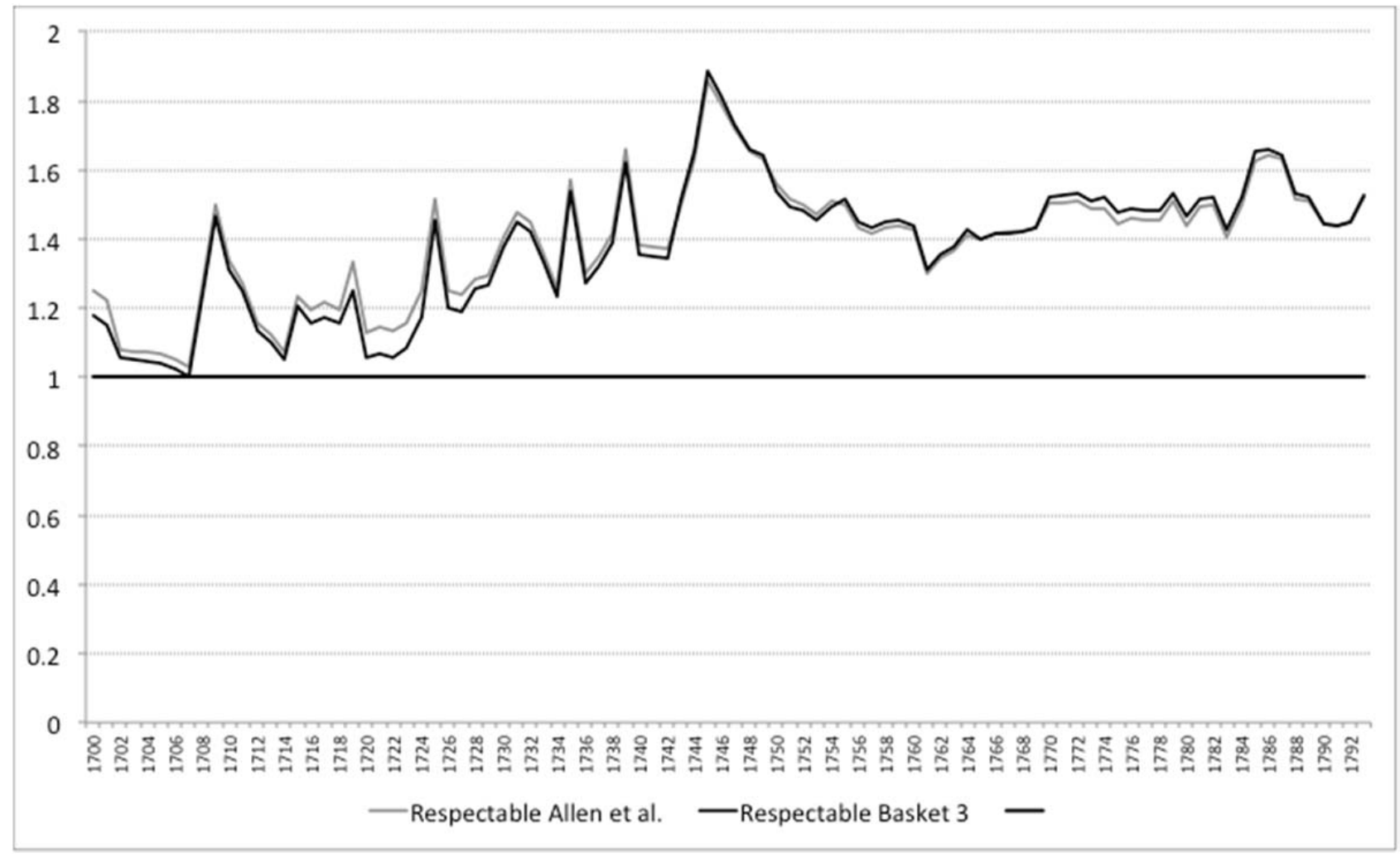

The welfare ratios, silver content and grain purchasing power comparisons reported here confirm the work of De Zwart (2011) on the increased welfare of unskilled labour at the Cape in the $18^{\text {th }}$ century. Skilled workers started the century at a higher level of welfare (even compared with workers linked to a more expensive consumption basket), and they also experienced a steady gain in welfare as the century unfolded. The few highest-paid company officials, such as the governor and the ministers of religion in Cape Town and Stellenbosch were already affluent by international standards as the century opened and saw their welfare rise steadily with the passing years. The vicar in Stellenbosch, for example, earned a salary more than six times the cost of Allen et al.'s (2005) respectable basket in 1700. By the end of the century, the incumbent in that post, Reverend Borcherds, could buy the respectable baskets almost 13 times over every year (his salary was recorded by Borcherds, 1861).

The mechanism which caused these welfare increases, a large and sustained decline in the price of important consumption goods, is consistent with Van Duin and Ross's (1987) earlier argument that the colonial economy showed steady production growth over the course of that century. By this mechanism, VOC officials enjoyed increasing prosperity, and the same trend would have been true of free burgers not on the Company's payroll.

\section{Conclusion}

This paper is the outcome of a study of the comparative welfare of VOC officials at the Cape during the $18^{\text {th }}$ century involving combining data on nominal wages and the prices of consumption goods. At 
the beginning of this period, a worker at the Cape would have experienced a comparatively low standard of living in an international comparison, a position that would have improved considerably over the course of that century. While nominal wages hardly moved, real wages rose sharply as prices declined. The position of a skilled worker was more favourable at the start of the period under consideration and also improved steadily over the course of the century.

These results have two implications: first, falling prices in the context of steadily expanding production suggests an expanding and more productive market economy, not over-supply, which would have led to contracting production over time. To put it differently, we have provided further evidence of a slowly but steadily expanding market economy at the Cape during the $18^{\text {th }}$ century which contradicts the stagnation thesis. Second, to the extent that rising real wages for VOC officials derived from falling prices (and not rising nominal wages), the opportunity for a higher standard of living would have been spread to the entire population, those who were happily employed by the company and the (perhaps even happier) free burgers. 


\section{Appendix 1}

Muster rolls from the Nationaal Archief, The Hague, used for wage data

\begin{tabular}{|c|c|c|}
\hline Contents & Archival Code & Period \\
\hline $\begin{array}{l}\text { Copia monsterrolle vant generaale guarnisoen danno } \\
\text { 1699-1700: voor Zeeland N:o } 43\end{array}$ & 12653 & $1699-1700$ \\
\hline $\begin{array}{l}\text { Generaale Monsterrolle des Casteels de goede Hoop } \\
\text { onder ult:o Junij } 1724 \text { voor Zeeland }\end{array}$ & 12537 & 1724 \\
\hline $\begin{array}{l}\text { Generaale Monster-rolle des Casteels de Goede Hoop } \\
\text { onder ultimo Junij } 1726 \text { voor de Caamer Zeeland }\end{array}$ & 12539 & 1726 \\
\hline $\begin{array}{l}\text { Vrij boek der Europiaanse Ingeseetenen des Casteels de } \\
\text { goede Hoop d' a:o } 17 \text { 4/45 van d' Camer Zeeland voor } \\
\text { Zeeland per Spanderwou }\end{array}$ & 12630 & 1745 \\
\hline $\begin{array}{l}\text { Per't schip Middelburg Generaale Monsterrolle des } \\
\text { Casteels de Goede Hoop onder ult:mo Junij } 1756 \text { voor } \\
\text { Zeelandt }\end{array}$ & 12561 & 1756 \\
\hline $\begin{array}{l}\text { Monsterrol van alle de Militairen het Guarnisoen } \\
\text { houdende Battallion van Cabo de Goede Hoop } \\
\text { uijtmaakende onder Ult:o Junij } 1772 \text { voor Zeeland }\end{array}$ & 12601 & 1772 \\
\hline $\begin{array}{l}\text { Monster Roll van alle de Militairen het Guarnisoen } \\
\text { houdende Bataillon onder ult: Juny } 1790 \text { uitmakende } \\
\text { voor de Camer Zeeland }\end{array}$ & 12602 & 1790 \\
\hline
\end{tabular}




\section{Appendix 2}

Table 2.1 Sources and conversion formulae for price data

\begin{tabular}{|c|c|c|c|c|}
\hline Item & Data Source & Unit in source data & $\begin{array}{l}\text { Unit in con- } \\
\text { sumption bas- } \\
\text { kets }\end{array}$ & Conversion formulae \\
\hline Grain & Scheepsoldijboeken & Mudde & $\mathrm{Kg}$ & $\begin{array}{c}111.5 \text { litres per mud (De } \\
\text { Zwart, 2011) and } 0.76 \\
\text { litres per kilogram (Allen, } \\
\text { 2001) }\end{array}$ \\
\hline Bread & Scheepsoldijboeken & Pound & $\mathrm{Kg}$ & $\begin{array}{c}0.49409 \mathrm{~kg} \text { per pound (De } \\
\text { Zwart, 2011) }\end{array}$ \\
\hline Beans & Scheepsoldijboeken & Mudde & $\mathrm{Kg}$ & $\begin{array}{l}111.5 \text { litres per mud and } \\
0.76 \text { litres per kilogram } \\
\text { (Allen, 2001) }\end{array}$ \\
\hline Meat & Scheepsoldijboeken & Pound & $\mathrm{Kg}$ & $0.49409 \mathrm{~kg}$ per pound \\
\hline Butter & Scheepsoldijboeken & Pound & $\mathrm{Kg}$ & $0.49409 \mathrm{~kg}$ per pound \\
\hline Soap & Scheepsoldijboeken & Pound & $\mathrm{Kg}$ & $0.49409 \mathrm{~kg}$ per pound \\
\hline Candles & Scheepsoldijboeken & Pound & $\mathrm{Kg}$ & $0.49409 \mathrm{~kg}$ per pound \\
\hline Lamp oil & Scheepsoldijboeken & Container (Kan) & Litre & $\begin{array}{l}1 \text { Kan equals } 1.51 \text { litres } \\
\text { (Kooijmans and } \\
\text { Schooneveld-Oosterling, } \\
\text { 2000) }\end{array}$ \\
\hline Cotton & Scheepsoldijboeken & Stuks Bafta & $\mathrm{m}^{2}$ & $\begin{array}{l}\text { Price per } \mathrm{m}^{2}: \frac{\text { BAFTA price }}{12.78 \times 0.93} \\
\quad \text { (De Zwart, 2011) }\end{array}$ \\
\hline Fuel & Scheepsoldijboeken & Vracht & MBTU & $\begin{array}{l}\text { Price per MBTU is: } \\
\frac{\text { Vracht price }}{1.58} \times 0.14(\mathrm{De} \\
\text { Zwart, 2011) }\end{array}$ \\
\hline Wine & $\begin{array}{c}\text { Van Duin and Ross } \\
\text { (1987) }\end{array}$ & Aam & Litres & $\begin{array}{l}1 \text { Aam is } 155.2 \text { litres } \\
\text { (Kooijmans and } \\
\text { Schooneveld-Oosterling, } \\
\text { 2000) }\end{array}$ \\
\hline
\end{tabular}




\section{Bibliography}

Allen, R. C. (2001). "The Great divergence in European Wages and Prices From the Middle Ages to the First World War." Explorations in Economic History 38: 411-447.

Allen, R. C. (2005). Real Wages in Europe and Asia: A First Look at the Longterm Patterns. Living Standards in the Past: New Perspectives on Well-Being in Asia and Europe. R. C. Allen, T. Bengtsson and M. Dribe. Oxford, Oxford University Press.

Allen, R. C., J. P. Bassino, et al. (2011). "Wages, prices, and living standards in China, 1738-1925: in comparison with Europe, Japan, and India." The Economic History Review 64(S1): 8-38.

Allen, R. C., J. P. Bassino, et al. (2005). Wages, Prices and Living Standards in China, Japan and Europe 1738-1925, Paper presented at the conference "The Rise, Organization, and Institutional Framework of Factor Markets" held at Utrecht University, June 23-25, 2005.

Biewenga, A. W. (1999). De Kaap de Goede Hoop. Een Nederlandse Vestiginskolonie., 1680-1730. Amsterdam, Prometheus-Bert Bakker.

Borcherds, P. B. (1861). An auto-biographical memoir of Petrus Borchardus Borcherds, Esq. Being a plain narrative of occurrences from early life to advanced age. Cape Town, A.S.Robertson.

Botha, G. (1962). General history and social life of the Cape of Good Hope. Cape Town, Struik.

Broadberry, S. and B. Gupta (2006). "The Early modern Great Divergence: Wages, Prices and Economic Development in Europe and Asia, 1500-1800." Economic History Review 59: 2-31.

Claassens, H. W. (2006). Die Geskiedenis van Boerekos 1652-1806. Pretoria, Protea Boekhuis.

De Zwart, P. (2009). Wages, Prices and Living Standards at the Cape of Good Hope, 1652-1704: In Comparison with Northwestern Europe. Utrecht, Utrecht University.

De Zwart, P. (2011). Real wages at the Cape of Good Hope: A long-term perspective, 1652-1912, CGEH Working Paper 13 (August 2011).

Giliomee, H. (2004). Die Afrikaners: n biografie. Cape Town, Tafelberg.

Kooijmans, M. and J. Schooneveld-Oosterling (2000). VOC-glossarium. Verklaringen van termen, verzameld uit de Rijks Geschiedkundige Publicatiën, die betrekking hebben op de Verenigde Oost-Indische Compagnie. Den Haag, Instituut voor Nederlandse Geschiedenis.

Nationaal Archief (2008). Rekeningen uit de Scheepssoldijboeken 1662-1805 (Accounts from Ships' Pay Ledgers 1662-1805). Den Haag, The Netherlands.

Nationaal Archief ( (ref. no.) 1.04.02). Prices rendementen verkoop extracted from the VOC Archive, with references: VOC 4177, 4180, 4182, 4185, 4187, 4193, 4199, 4207, 4221, 4224, 4233, 4238, 4241, 4245, 4253, 4257, 4265, 4268, 4277, 4280.

Parthsarathi, P. (1998). "Rethingking wWages and Competitiveness in the Eighteenth Century: Britain and South India." Past \& Present 158(1): 79*109.

Ross, R. (1986). The Origins of Capitalist Agriculture in the Cape Colony: A Survey. Putting a Plough to the Ground: Accumulation and Disposession in Rural South Africa, 1850-1930. W. Beinart, P. Delius and S. Trapido. Johannesburg, Ravan Press.

Ross, R. (1989). The Cape of Good Hope and the World Economy, 1652-1835. The Shaping of South African Society, 1652-1840. H. Giliomee and R. Elphick. Cape Town, Wesleyan.

Schutte, G. (1979). Company and Colonists at the Cape. The Shaping of South African Society. R. Elphick and H. Giliomee. London, Longman.

TEPC (2008). Verbatim Copies in the Cape Town Archives Repository and digital images of Cape documents in the Nationaal Archief,The Hague, regarding VOC employees (1656-1790). Cape Town, TEPC Project and Sentrum vir Besigheids- en Taaldiens. 
Van Duin, P. and R. Ross (1987). The Economy of the Cape Colony in the eighteenth century. Leidein, Intercontinenta no 7.

van Zanden, J. L. (2008). Prices and wages and the cost of living in the western part of the Netherlands, 1450-180. International Institute of Social History List of Datafiles of Historical Prices and Wages. Amsterdam. Available online at: http://www.iisg.nl/hpw/brenv.php.

Van Zyl, D. J. (1966). Kaapse Wyn en Brandewyn, 1795-1866. Cape Town. 